مجلة كلية التربية بالإسماعيلية - العدد الرابع والأربعون - مايو 9 بـ

\title{
Using Pictorial Stories for the Acquisition and Retention of English Vocabulary in Kindergarten ${ }^{\bullet}$ \\ BY
}

\author{
Mai Ahmed Eassa El-Nekhely * \\ Prof. Ahmad H. Seif El-Dien** Dr.Taher M. Al-Hadi***
}

Dr. Manal M. Khodary****

\section{Introduction}

The Kindergarten phase is so important. When children go to a kindergarten, they experience greater success once they enter elementary school. Children's early learning experiences have a profound effect on their development and success in school (Miedel and Reynolds, 1999). Vocabulary is so important for communication.

Wilkins (1972) stated that "without grammar, very little can be conveyed; without vocabulary nothing can be conveyed." (p. 111). Other researchers (e.g. Herman and Dole, 1988; Leny, 2006) assured that the mastery of vocabulary is useful for the mastery of language skills (listening, speaking, reading, and writing).

As for kindergarten children, it is so important to teach them vocabulary in their early years. Justice and Pullen (2003) mentioned that children, who face difficulties in their acquisition of vocabulary, might fall behind their peers in the primary grades. Since learning a foreign language is essential especially in the Kindergarten stage, as children tend to absorb foreign languages more easily than older students and adults (Abbott and Stewart, 2007; Folse, 2004; Putri, 2010), vocabulary is more important in learning a foreign language.

-A research based on a thesis for the requirements of the M.Ed. Degree in Education.

*M.Ed. Student at Faculty of Education, Suez.

** Prof. of Curriculum \& Instruction (TEFL), Faculty of Education, Shebeen El-Koum.

***Assistant Professor of Curriculum \& Instruction (TEFL), Faculty of

Education, Ismailia.

$* * * *$ Lecturer of Curriculum \& Instruction (TEFL), Faculty of Education, Ismailia. 
It is not only important to make kindergarten children acquire new vocabulary, but it is important, as well, to make them retain the new words in their long-term memory and be able to recall them when needed. One of the techniques used to help in the acquisition and retention of vocabulary is the use of pictorial stories. Thornbury (2004) stated that using pictorial stories contributes much to the acquisition and retention of new vocabulary. He assured that they are very interesting to children as they are attracted to the colorful and interesting pictures and they can introduce the vocabulary through the vivid pictures and the meaningful contexts.

In an attempt to determine some of the problems that encountered the second phase of kindergarten children in learning English vocabulary in experimental English language schools, the researcher conducted a pilot study having a questionnaire forwarded to experts in kindergarten and English teachers of KG2 children. Besides, she tested KG2 children. The results of the questionnaire and the test showed that KG2 children had a difficulty in acquiring and retaining the English vocabulary and that the method of teaching the English vocabulary was conventional and depended on the direct approach represented in repeating the vocabulary and explaining it through pictures and flash cards. They also showed that pictorial stories were infrequently used in the English sessions.

The results also showed that KG2 children faced the following problems: pronouncing the English vocabulary correctly, distinguishing colors, identifying numbers, naming body parts, knowing the names of some animals and birds, identifying different kinds of food, naming different things in their environment and distinguishing location words (prepositions). Thus, the researcher thought that preparing a program based on the use of pictorial stories could help KG2 children to acquire and retain the English vocabulary in their set book My English Activity Book II and could help them in facing such problems.

\section{Problem of the Study}

Kindergarten children of the second phase (KG2) had many problems in learning English vocabulary in their set book My English Activity Book II. They were unable to acquire and retain most of the vocabulary. The study tried to answer the following question:

How far is using pictorial stories effective in the acquisition and retention of English vocabulary of Kindergarten Children?

Some sub-questions were also derived : 


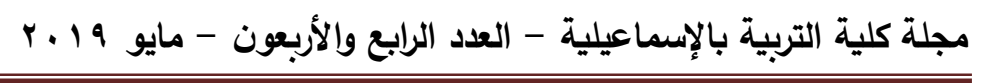

1. What is the conception of presenting the English vocabulary through pictorial stories?

2. What is the effect of pictorial stories on the acquisition of the English vocabulary?

3. What is the effect of pictorial stories on the retention of the English vocabulary?

Aims of the Study

1. Developing a pictorial stories-based program.

2. Determining the effect of pictorial stories on the acquisition of the English vocabulary.

3. Determining the effect of the pictorial stories on the retention of the English vocabulary.

Significance of the Study

1. It may open the field of conducting researches in teaching EFL to kindergarten children in experimental English language schools in Egypt.

2. It may provide kindergarten teachers (facilitators) with motivating methods of instruction for kindergarten children to learn English vocabulary in EFL classes.

3. It may increase the English vocabulary that kindergarten children in experimental English language schools learn and help them acquire and retain it in an interesting way.

4. It may urge experts of English curriculum of kindergarten children in experimental English language schools in Egypt to use pictorial stories and motivating activities in teaching vocabulary.

Variables of the Study

1. The independent variable: Pictorial stories.

2. The dependent variables:

- The acquisition of the English vocabulary.

- The retention of the English vocabulary.

\section{Limitations of the Study}

1. Kindergarten children of the second phase (KG2) at Suez Experimental English Language School.

2. The first term of the school year 2011-2012.

3. Fifty-two vocabulary words in the set book My English Activity Book II of (KG2) children.

Instrument of the study

The instrument of the study was a Vocabulary and Retention (VAR) Test that was administered: 
- pre the PSBP for measuring the equivalence of both the control and experimental groups in their knowledge of the target vocabulary.

- post the PSBP to measure the acquisition of target vocabulary of both the control and experimental groups.

- delayed Post the PSBP to measure the retention of the target vocabulary of the experimental group.

\section{Hypotheses of Study}

1. There would be no statistically significant difference in the mean gain scores of the control group and that of the experimental group on the post-administration of the VAR Test for determining the acquisition of the target vocabulary.

2. There would be no statistically significant difference in the mean gain scores of the experimental group which was exposed to the pictorial stories on the pre-administration and the postadministration of the VAR Test for determining the acquisition of the target vocabulary.

3. There would be no statistically significant difference in the mean gain scores of the experimental group on the postadministration and the delayed post-administration of the VAR Test for determining the retention of the target vocabulary.

\section{Definition of Terms}

\section{Vocabulary Acquisition}

Vocabulary acquisition is operationally defined as "the process of receiving vocabulary indirectly in a way that enables the children to recognize the form of the word and pronounce it".

\section{Vocabulary Retention}

Vocabulary retention is operationally defined as "the process of visually receiving the vocabulary and maintaining it in the longterm memory and recalling it when needed".

\section{Pictorial Stories}

Pictorial stories are operationally defined as "a mixture of both pictures and words forming a story that help the children of the second phase of kindergarten to acquire and retain the English vocabulary".

\section{Review of Literature and Related Studies}

\section{Characteristics of Kindergarten Children}

A. Physical, Socio-emotional and Intellectual Development

Leny (2006) pointed out that most kindergarten children are full of energy and are active in doing physical activities such as 
مجلة كلية التربية بالإسماعيلية - العدد الرابع والأربعون - مايو 9 بـ

running, swinging, climbing, jumping, etc. He assured that such activities are very useful to the development of their body and are related to the children's muscles, nerves and brain. Regarding the socio-emotional development of kindergarten children, Halliday (1988), stated that kindergarten children can show considerable empathy toward people and animals when their own needs do not conflict with the needs of others. As for the intellectual development, Leny (2006) stated that Kindergarten children's intellectual development is reflected in the rapid growth of vocabulary and the power to express ideas. Vygotsky (1989) assured that it is reflected in the children's development of visual and auditory memory and the ability to listen to others, the powerful urge to find out about things and their joy of listening to stories.

B. Linguistic Development

Ibrahim (1987) stated that teaching kindergarten children linguistic skills involves helping them pronounce the sounds correctly, allowing them to distinguish between different sounds, such as the sounds of different animals and birds, helping them see the lips of the speaker to imitate her/him and explaining to them the meaning of sounds and words. Sherif (1990) demonstrated some skills involved with vocabulary learning in kindergarten such as: visual perception skills, audio perception skills, audio-visual perception skills, visual recall and audio recall skills. El-Bosat (2005) also stated that kindergarten children at this age like listening to stories, singing songs, drawing and coloring.

Vocabulary Acquisition

Nation (2001) defined vocabulary acquisition as the process by which humans acquire the capacity to perceive, produce and use words to understand and communicate and are able to recognize the form of the word, retrieve the meaning, and use it appropriately. For vocabulary acquisition, Pinkley (2009) identified five strategies which are: determination strategies that include analysis of parts of speech, analysis of word prefixes, roots, and suffixes, figuring out meaning from context and using dictionaries, social strategies that involve using synonyms and translation of vocabulary, cognitive strategies which involve making word lists, verbal and written repetition, metacognitive strategies which include working with English songs, chants, poems and stories and memory strategies which include word recycling, visualization, vocalizing and using physical movement. 
As for EFL KG2 children, the researcher combined metacognitive and memory strategies for the acquisition and retention of English vocabulary. Pictorial stories were used for acquiring the target vocabulary with the aid of using follow-up activities, such as songs, role plays, physical movement and games. To help the children retain the target vocabulary, the researcher used visualization by using flash cards to help the children match the target vocabulary with its suitable pictures and spaced recycled exercises in the form of revisions.

Vocabulary acquisition is important during the first years of a child's life. This is because vocabulary acquisition in kindergarten leads to greater success in school (Biemiller, 2003; Bromley, 2007). Researchers (e.g. Alexander, 1996; Folse, 2004; Gass and Selinker, 1994) stressed that communication in any foreign language could not happen in any meaningful way without learning and acquiring vocabulary. As for the order of development of children's vocabulary, Nelson, (cited in Kies, 2009), observed that children learn nouns earlier than verbs and they learn meaningful, content words before grammatical function words. She explained that action words are abstract, while nouns can function as names representing static and concrete entities in the child's environment.

Wilkins (1972) classified methods of vocabulary instruction into two approaches: direct and indirect approaches. Researchers (e.g. Schmitt, 2000; Sokmen, 1997) referred to these approaches as explicit and implicit. Laufer (2001) pointed out that incidental vocabulary learning reflects the implicit approach, while the intentional vocabulary learning reflects the explicit approach. He suggested that the intentional vocabulary acquisition refers to an activity aiming at committing lexical information to memory, while the incidental vocabulary acquisition means that learners acquire the vocabulary incidentally when they are carrying out other learning tasks, such as, reading articles and listening to stories. Researchers had different opinions about the use of both approaches. Some favored the use of the indirect approach, such as (Collins, 2010; Day, Omura, and Hiramatsu, 1991). Other researchers favored the direct approach, especially in EFL kindergarten classes (e.g. Baker, (cited in Brabham and Villaume, 2002; Khedr, 2007). A third group of researchers suggested the importance of using both methods (e.g. Hunt and Beglar, 2005; National Reading Panel, 2000; Pinkley, 2009). 
مجلة كلية التربية بالإسماعيلية - العدد الرابع والأربعون - مايو 19 ب P

Vocabulary Retention

Abd El-Razek (1995) defined retention as "a process of maintaining impressions in the memory" (p.85). One of the techniques of vocabulary retention is repetition and recycling of words. August, Carlo, Dressler and Snow (2005) stated that EFL learners who receive elaborate teaching of new words through repetition and recycling, have better recall of the words than those who do not. Another technique is the use of pictures. The use of pictures facilitates learning as they are more distinctive and more unique than the words that label them, and this would make words more memorable (Sadeghi, 2007). Mohamed (2004) identified three other techniques of vocabulary retention: production of words, motivation on part of the learners and rehearsal expansion. She stated that word memorization is affected more when the learner produces words in speaking and writing and not just receives words, in reading and listening. Moreover, if the learners are highly motivated to learn, they will memorize words in a better way. Last but not least, if activities are introduced to them to review words at intervals, which is meant by rehearsal expansion, they will remember and recall more words. Last but not least, stories are considered to be another important technique in helping children retain vocabulary. They motivate them and attract their attention through their interesting contexts, such as pictorial stories.

\section{Pictorial Stories}

Janes, (cited in Abd El-Latif, 2007), mentioned that pictorial stories are composed of several elements which are: theme, plot, characters, setting, style and pictures. The theme should be clear for the children and could be about real-life situations, domestic activities, friendship or family relations. As for the plot, she pointed out that it should be clear and easy for the children to follow; the characters should be few, interesting and memorable, such as: talking animals and objects. To Diab (1999), the setting, which includes the place and the time of the story, should be clear; the place could be a small place like a farm, a house or a classroom, and the time could be about the past, the present or the future. Researchers (e.g. El-Gadry, 2003; Brown, 2004) recommended that the style be simple so that the children could understand the story and the pictures should be exciting, big, and colorful and they should illustrate the actions of the story.

Herendeen (1995) and Sherif (1990) clarified the characteristics of pictorial stories and stated that they should be simple, short in 
length and interesting and they should be suitable for the children's age and their cultural background. The language used should be suitable for the children's level and the cover should attract the child with its beautiful colors and the title's big bold letters (El-Hadidy, 1996; Hussein, 1999). The written words should be few, simple and typed in big letters and they should refer to concrete and not abstract items (El-Tartoory, 2009; Mukdady, 2007; Nassar, 2008).

The importance of pictorial stories for Kindergarten children lies, first, in the use of pictures which make words more memorable. Najjar (1998), who found out that pictures help children acquire vocabulary more effectively than text alone, assured that combining pictures and texts are more effective when teaching vocabulary. Second, contextualization is so important in pictorial stories. As for learning EFL vocabulary, Mustafa (2002) and Alqahtani (2009) pointed out that putting the isolated vocabulary into meaningful and interesting contexts helps EFL learners to acquire and remember larger numbers of words and develops their enthusiasm in learning the foreign language.

\section{Procedures of Teaching Vocabulary through Pictorial Stories}

The instructional goals of the material should be determined first to choose the target vocabulary that will be taught through the pictorial stories and the target vocabulary that is to be taught through pictorial stories should be related to aspects which are relevant and significant for students' motivation (Greenwood and Flanigan, 2007). The pictorial story must reflect the curriculum and it should realize the linguistic objectives the teacher wants the children to learn (Martinez, 2007). The number of vocabulary that is intended to be taught to children through a pictorial story was suggested by McGee and Schickedanz (2007) to range from (5-10) vocabulary words. The teacher should decide a time plan for presenting the story. The target vocabulary could be presented first to the children, before reading the story by using pictures or flashcards (Martinez, 2007).

Blachowicz, Fisher and Watts (2006) believed that there are methods that a teacher can apply to determine which vocabulary will be chosen from the curriculum and used through the pictorial stories. Those methods might include picking the words that are not well mastered in the students' vocabulary and will be encountered frequently in the future. It is important - in August, Carlo, Dressler and Snow's (2005) view - to choose the vocabulary which the 
مجلة كلية التربية بالإسماعيلية - العدد الرابع والأربعون - مايو 19 ب P

learners will encounter regularly and have relationships, i.e. words that start or end with the same letter or sound.

Style of Presenting Pictorial Stories

There are two styles of presenting stories, storytelling and story reading (Hussein, 1999). In order to either build vocabulary or increase comprehension, Dickinson and Smith (1994) thought that reading the story for one time is not sufficient. As for storytelling, Vernon (2008) stated that story telling is the use of voice and gesture to tell a story. He added that it can be enhanced by using colorful illustrations, relevant games and role-plays. Cullinan and Galda, (cited in $\mathrm{Wu}, 2008$ ) mentioned that story reading is more preferable when pictorial stories are used with children, as they are usually well designed so as to be read aloud to children long before they are read individually by children. Thus, the researcher used story reading.

\section{Considerations of Presenting Pictorial Stories}

Wright (2000) stated some of the basic considerations when presenting a story. He are some: the listeners have to be prepared for the idea of the story; teachers should concentrate on how to give their feelings about the story to the listener rather than thinking about themselves and they should tell the story with feeling and change tone and use body language while reading the story. Saeed (2007) recommended the use of audio visual teaching aids such as the computer in presenting stories. Almekhafi (2006) found out that the use of Computer Assisted Language Learning (CALL) improved learning foreign languages.

Commentary on the Literature Review and Related Studies

The researcher in the present study benefited much from the related studies. Some of them were related to the use of stories, such as the studies of (Ahmed, 1994; El-Monayyer, 2002; Isbell, Sobol, Lindauer and Lowrance, 2004; Ahmed, 2005). Others were related to vocabulary acquisition (e.g. Senechal, 1997; Crawford and Hade, 2000; Brooks, 2006; Walsh and Blewitt, 2006; Christ, 2007; Iannucii, 2007). Other studies were related to vocabulary retention (e.g. Senechal and Cornell, 1993; Suzuki and Takahashi, 2002; Stewart, Heimdal, Hanson, Remhoff and Roy, 2011).

Apart from their help in determining the design of the study which was the quasi-experimental design, they helped in preparing the instruments of the study which were the pre, post and delayed post tests. They also helped in developing the PSBP. For example, studies, such as (Ahmed, 2005; Christ, 2007; Crawford and Hade, 
2000; Isbell, Sobol, Lindauer and Lowrance, 2004) helped in determining kinds of stories. Studies of (Crawford and Hade, 2000) helped in determining the elements and characteristics of pictorial stories. The study of (El-Monayyer, 2002; Walsh and Blewitt, 2006) helped the researcher in setting the strategy of presenting the pictorial stories and their target vocabulary.

Moreover, the study of (Suzuki and Takahashi, 2002) helped the researcher in designing the pictorial stories. The researcher also benefited from the studies of (Ahmed, 2005; El-Monayyer, 2002) in setting the lesson plans of the pictorial stories and determining the follow-up activities and the skills related to them. Concerning the suitable approach of presenting the target vocabulary in the present study, the studies of (Brooks, 2006; Iannucii, 2007) helped in choosing it, which was both the direct and indirect approaches. The direct approach was applied through vocabulary explanation by using flash cards, repetition of the vocabulary and the use of spaced recycled exercises. The indirect approach was applied through the use of the pictorial stories.

As for the style of presenting the pictorial stories, the researcher used the story reading style, as the studies of (Brooks, 2006; Christ, 2007; Iannucii, 2007; Senechal and Cornell, 1993; Stewart, Heimdal, Hanson, Remhoff and Roy, 2011; Walsh and Blewitt, 2006) favored that style. Moreover, the researcher benefited from the study of (Stewart, Heimdal, Hanson, Remhoff and Roy, 2011) in determining the number of the target vocabulary and the convenient period for teaching it. She also benefited from studies of (Senechal and Cornell, 1993; Stewart, Heimdal, Hanson, Remhoff and Roy, 2011) in determining the period before administering the delayed post test, which was three weeks.

Although, the present study had points of similarities with the related studies, such as using pictorial stories for the acquisition and retention of vocabulary in kindergarten classes, it differed with them. The difference was that the present study used pictorial stories in EFL kindergarten classes to evaluate their effect on both the acquisition and retention of English vocabulary, whereas the related studies that used pictorial stories in EFL kindergarten classes, such as the study of (Silverman, 2007) used pictorial stories for investigating their effect on the acquisition of English vocabulary only. 
مجلة كلية التربية بالإسماعيلية - العدد الرابع والأربعون - مايو 19 ب P

Method and Procedures

This study was a quasi-experimental study. It included two groups: a control group and an experimental one. The two groups were drawn randomly from the second phase of kindergarten at Suez Experimental English Language School. The experiment took 66 days during the first term of the school year 2011-2012. The two groups were pre tested before conducting the experiment for measuring their equivalence in the target vocabulary. During the experiment, the researcher taught the experimental group the target vocabulary directly and indirectly by using a pictorial stories based program PSBP, through ten pictorial stories, follow-up activities and five revisions, which were all prepared by the researcher. On the other hand, the control group was taught the target vocabulary directly, and it was exposed to the follow-up activities and the revisions of the PSBP, but it was not exposed to the pictorial stories. At the end of the experiment, the two groups were post tested to measure their acquisition of the target vocabulary. Then, the experimental group received a delayed post test three weeks after applying the PSBP to measure its retention of the target vocabulary.

Participants of the Study

The participants of the study, 46 children, were randomly drawn from Suez Experimental English Language School during the first term of the school year 2011-2012. They were drawn from the second phase of kindergarten KG2. The children's age ranged between (5-6) years old. They consisted of two classrooms which were already assigned by the school. The researcher chose one classroom to represent the control group (23 children) and the second classroom to represent the experimental group ( 23 children). The reasons for choosing the participants from the second phase of kindergarten (KG2 children) were as follows: they were older than KG1 children, so the PSBP could be more appropriate to be used with them, they could be easily controlled by the researcher and they were more disciplined than the younger children and the rate of absence was less in the older children, so it was easier to conduct the experiment with them.

\section{Instrument of the Study}

In order to develop the instrument of the study, the researcher reviewed many studies and books written by different researchers (e.g. Brooks, 2006; Iannucii, 2007; Ibrahim, 1987). For instance, Ibrahim (1987) clarified some tests used with kindergarten children, such as: the Multiple Choice Test in which the child puts a circle 
around the correct picture. There was also the Matching Test in which the child matches between two pictures or between a picture and a word or letter. There were also the vocabulary tests, such as the Expressive One-Word Picture Vocabulary Test (EOWPVT), which assesses the child's English speaking vocabulary, as the child is shown a picture and asked to give one word that best describes the picture. The instrument of the study was the Vocabulary Acquisition and Retention (VAR) Test that was administered pre, post and delayed post the PSBP. The pre-administration of the test was intended to measure the equivalence of both the control and experimental groups of KG2 children in their knowledge of the target vocabulary of the study. The post-administration was intended to measure the acquisition of the target vocabulary of both the control and experimental groups after administering the PSBP to the experimental group. The delayed post-administration measured the retention of the target vocabulary of the experimental group after three weeks of applying the PSBP.

Each of the pre, post and delayed post-administration of the VAR Test was composed of three sections. They were: Section 1, which was Pointing at the Pictures, Section 2, which was Naming the Pictures and Section 3 which was composed of two parts: the first part was The Matching Questions and the second part was the Multiple Choice Questions. In Section 1, the child was asked to point at one of four different colored pictures in a single flash card after she/he had listened to the word that represented it. In Section 1, the researcher adapted the same idea of the Peabody Picture Vocabulary Test (PPVT-III). In Section 2, the child was asked to name the picture by using one word only. In every flash card, there were three different colored pictures in which the child had to give the name of each picture. Section 3 was composed of two different parts. The first part was composed of the Matching Questions. In that part, the child was asked to match each picture with its suitable word. In the second part, which was the Multiple Choice questions, the child was asked to round the picture that described the word that represented it.

Validity of the Vocabulary Acquisition and Retention (VAR) Test

\section{Face Validity (Judgmental Validity)}

In order to achieve face validity, the researcher submitted the three Sections: 1, 2 and 3 to some jurors - a group of experts at some faculties of Education - to see if the tests were valid. The jury 


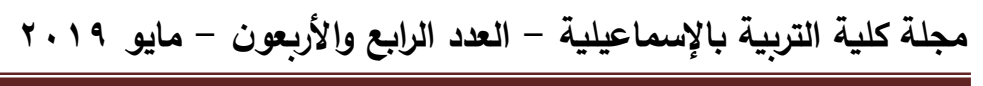

consisted of ten experts in curriculum and TEFL instruction, kindergarten and English language experts.

\section{Content Validity}

Content validity means that "the items on the test represent the entire range of possible items the test should cover" (Cherry, 2011). The researcher covered in the Sections 1, 2 and 3 all the target vocabulary in the PSBP, i.e. the tests represented all the items that should be covered. This was also approved by the jury members who indicated that the Sections covered all the target vocabulary in the PSBP.

Reliability of the Vocabulary Acquisition and Retention (VAR) Test

\section{Internal Consistency Method}

A pilot sample of $20 \mathrm{KG} 2$ children, out of the sample of the study, was used for applying the Kuder-Richardson formula 21 to them in order to calculate the reliability coefficient. That took place during the second term of the school year 2010-2011 at Suez Experimental English Language School. The following table shows the VAR Test's coefficient reliability by using Kuder-Richardson formula 21:

Table (1) Coefficient Reliability of the VAR Test by Using KuderRichardson Formula 21

\begin{tabular}{|c|c|c|c|}
\hline $\mathbf{X}$ & $\mathbf{k}$ & $\mathbf{s}^{2}$ & $\mathbf{R}$ \\
\hline $\mathbf{3 6 . 3 8}$ & $\mathbf{5 2}$ & $\mathbf{6 5 . 8 8}$ & $\mathbf{0 . 8 3}$ \\
\hline
\end{tabular}

The coefficient reliability $(R=\mathbf{0 . 8 3})$ was valued as high.

\section{Test Retest Reliability}

A pilot sample of $20 \mathrm{KG} 2$ children, out of the sample of the study, was used for the test retest reliability during the second term of the school year 2010-2011 at Suez Experimental English Language School by performing the three Sections 1,2 and 3 twice. The time between the two administrations was two weeks to ensure that the children would not remember their answers from the first administration. The first and second administrations were correlated by using Spearman's Coefficient of rank correlation by using the following formula:

$$
R=1-\frac{6 \sum d^{2}}{n\left(n^{2}-1\right)}
$$

where:

$\mathbf{R}=$ Spearman's rank correlation coefficient 
$\mathrm{d}=$ the difference between the ranks

$n=$ the number of the sample

Table(2) shows Spearman's rank correlation coefficient.

Table (2). Spearman's Rank Correlation Coefficient

\begin{tabular}{|c|c|c|}
\hline $\mathbf{n}$ & $\sum \mathbf{d}^{2}$ & $\mathbf{R}$ \\
\hline 20 & $\mathbf{2 1 2 . 5}$ & $\mathbf{0 . 8 4}$ \\
\hline
\end{tabular}

Since the correlation coefficient was $(R=0.84)$ which was significant at the 0.05 level, the Sections 1,2 and 3 were reliable.

\section{Piloting the VAR Test}

The three Sections, 1, 2 and 3, were used with a pilot group of 20 KG2 children out of the sample of the study during the second term of the school year 2010-2011. The pilot group was randomly drawn from KG2 children at Suez Experimental English Language School. The purpose of administering the three Sections to the pilot group was to find out whether the questions were suitable and easy for the children, whether the pictures in every question were clear and to determine the time needed for the children to answer every test. The three Sections were used with every child at a time and each test was used on a different day to lessen the pressure on the children. As for the time of every Section, 10 minutes was considered to be the appropriate time for Section 1, 15 minutes was seen to be the appropriate time for Section 2 and 30 minutes was found the appropriate time for Section 3. Thus, 55 minutes was considered to be the appropriate time for each of the VAR Test.

\section{Instructional Materials of the Study}

Instructional Materials were divided into technology-based materials, such as "PowerPoint program", audio tapes and printed materials, such as "pictures and clip arts", and the school set book My English Activity Book II.

\section{Developing the Pictorial Stories-Based Program}

After setting the principles of the pictorial stories-based program (PSBP) and its aims, the researcher determined its content as follows:

\section{Determining the Target Vocabulary}

The reasons for choosing the target vocabulary of the PSBP were: they were included in the English curriculum of KG2 children in their set book My English Activity Book II; they related to aspects which are relevant and significant for the children's motivation, such as: animals and birds, the environment, body parts, colors, numbers and food; and some of the target vocabulary words had relationships, i.e. words that started, ended with or contained the 
مجلة كلية التربية بالإسماعيلية - العدد الرابع والأربعون - مايو 9 بـ

same letter or sound which would help KG2 children in their pronunciation. The total number of the target vocabulary was 52 .

2. Preparing the Pictorial Stories

The PSBP included ten pictorial stories prepared by the researcher. The pictures were adopted from the pictures and clipart websites on the Internet. Some of them were modified by the researcher by using the Paint Program to fit some actions of some of the stories. Some criteria were taken into consideration for the preparation of the pictorial stories, such as: the characteristics of pictorial stories, the elements of pictorial stories, motivation and attraction and the learning element. This involved the learning of the target vocabulary and its pronunciation, its acquisition, and retention through the motivating contexts, the recycling of words in some pictorial stories. Each pictorial story was followed by some follow-up activities which were prepared by the researcher to help KG2 children acquire and retain the target vocabulary. After every two pictorial stories were presented with their target vocabulary and their follow-up activities, a revision, formed of spaced recycled exercises, was given to help KG2 children in retaining the target vocabulary of the two pictorial stories that were taken.

It was more effective to use both approaches which are the direct approach and the indirect approach. The direct approach was represented in defining and explaining the target vocabulary through flashcards, whether before, during or after presenting the pictorial stories. It was also represented in the use of the follow-up activities, and the repetition of some of the target vocabulary words in the spaced recycled exercises of the revisions. On the other hand, the indirect approach was represented in introducing the target vocabulary through the pictorial stories.

\section{Preparing the Lesson Plans of the Pictorial Stories}

The main points of preparing the lesson plan of every pictorial story were: determining the target vocabulary, the related skills, deciding the time and the place of the session, determining the objectives of the lesson, the teaching aids and the follow-up activities. It was determined to implement the PSBP at Suez Experimental English Language School. The reasons for choosing the school are: it is a governmental school that provides the learning of the English language as a foreign language in the kindergarten's curriculum; the school provides the most suitable and modern teaching aids. 
4. Setting the Strategy of Implementing the PSBP

The strategy was divided into three steps: preparing the children to listen to the pictorial stories, presenting the pictorial story and the target vocabulary and evaluating the children's acquisition of the target vocabulary. Then the researcher determined the teaching aids which were visual, audio and audio-visual aids.

After validating the PSBP and the pictorial stories by submitting them to a jury of ten experts in curriculum and TEFL instruction, kindergarten, English language and literature, some of the pictorial stories and their follow-up activities were used with a pilot group of $20 \mathrm{KG} 2$ children out of the sample of the study at Suez Experimental English Language School during the second term of the school year 2010-2011. The reasons for piloting the pictorial stories were to make sure that the stories were suitable for KG2 children in terms of their age and cultural background. The second reason was to determine the exact number of the classes that should be assigned for each pictorial story regarding its target vocabulary. The third reason was to make sure of the convenience of the teaching aids, the lesson plans, the objectives, the strategy of presenting the pictorial stories and the target vocabulary and the follow-up activities to the characteristics of KG2 children.

\section{Administering the VAR Test Pre PSBP}

After drawing the sample of the study, the researcher had to make sure that both the control and the experimental groups were homogeneous and equivalent in their knowledge of the target vocabulary. They were both pre tested by administering three Sections prepared by the researcher to the two groups. The preadministration of the VAR Test started on the ninth of October and ended on the thirteenth of October in 2011. To reassure the homogeneity of both the control and the experimental groups and that they were both equivalent in their knowledge of the target vocabulary, the researcher used two tests which were the F-Test and the Two-Tailed t-Test. Table 3 shows the results of the F-Test. 


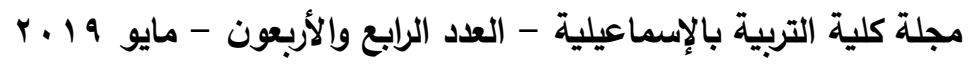

Table 3. F-Test for the Difference in the Mean Scores of the VAR Test of Both the Control and the Experimental Groups Pre Administering PSBP

\begin{tabular}{|c|c|c|c|c|}
\hline Group & Mean & Variance & DF & Calculated F- Value \\
\hline Control & 11.04 & 19.26 & \multirow{2}{*}{22,22} & 1.07 \\
\hline Experimental & 11.39 & 20.63 & & \\
\hline
\end{tabular}

Since the calculated F-value (1.07) was smaller than the F-Test value $(F=2.07, p>0.05)$, the two groups were homogeneous. Table 4 shows the result of the two tailed t-Test.

Table 4. Two-Tailed t-Test for the Difference in the Mean Scores of the VAR Test of Both the Control and the Experimental Groups Pre Administering PSBP

\begin{tabular}{|c|c|c|c|c|c|c|}
\hline Group & Test & Mean & $\begin{array}{c}\text { Standard } \\
\text { Deviation }\end{array}$ & $\begin{array}{c}\text { Deviation } \\
\text { Error }\end{array}$ & DF & T-Value \\
\hline Control & Pre & 11.04 & 4.39 & & \multirow{2}{*}{44} & 0.28 \\
\hline Experimental & Pre & 11.39 & 4.54 & 1.26 & 44 \\
\hline
\end{tabular}

Since the calculated T-value $(0.28)$ was smaller than the Twotailed $t-$ Test value $(t=2.02, p>0.05)$, there is no statistically significant difference in the mean scores of the VAR Test of both the control and the experimental groups pre PSBP. This result revealed that both groups were equivalent in their knowledge of the target vocabulary.

\section{Administering the VAR Test Post PSBP}

After applying the PSBP on the experimental group in 33 days, the post-administration was to measure the acquisition of the target vocabulary of both the control and experimental groups of KG2 children. It started on the eleventh of December and ended on the fifteenth of December in 2011.

\section{Administering the VAR Test Delayed Post PSBP}

Then, the delayed post administration was to measure the retention of the target vocabulary of the experimental group. Since Rea and Modigliani, (cited in Grace, 1998), pointed out that the spacing of intervals between the post and the delayed postadministrations of tests should be of an expanding nature, and reviewing the studies of (Senechal and Cornell, 1993; Stewart, Heimdal, Hanson, Remhoff and Roy, 2011; Suzuki and Takahashi, 2002), a period of three weeks after applying the PSBP was found appropriate to administer the VAR Test. The delayed postadministration started on the twenty-seventh of December and ended on the twenty-eighth of December in 2011. 


\section{Results of the Study}

1. A statistically significant difference was found in the mean scores of the post-administration of the VAR Test attained by both the control and experimental groups for determining the acquisition of the target vocabulary in favor of the experimental group and it showed that the pictorial stories were effective for the vocabulary acquisition of the experimental group.

2. A statistically significant difference between the pre and post administrations of the VAR Test was found in the mean scores attained by the experimental group which was exposed to the pictorial stories for determining the acquisition of the target vocabulary in favor of the post-administration and it showed that the pictorial stories were effective for vocabulary acquisition.

3.No statistically significant difference between the post and delayed post-administration of the VAR Test was found in the mean scores attained by the experimental group for determining the retention of the target vocabulary. The result showed that the pictorial stories were effective for vocabulary retention of the experimental group. The following tables show the statistical results as follows:

Table 5. Two-Tailed t-Test for the Difference in the Mean Scores of the VAR Test of both Control and Experimental Groups for Vocabulary Acquisition Post PSBP

\begin{tabular}{|c|c|c|c|c|c|}
\hline Group & Mean & $\begin{array}{c}\text { Standard } \\
\text { Deviation }\end{array}$ & Deviation Error & DF & t-Value \\
\hline Control & 30.35 & 5.45 & & & \multirow{2}{*}{6.24} \\
\hline Experimental & 44.02 & 9.03 & 44 & 6.1 \\
\hline
\end{tabular}

Since the calculated $t$-value (6.1) is bigger than the two-tailed $T$ - Test value $(t=2.02, p<0.05)$, there is a statistically significant difference in the mean scores of the VAR Test of both the control and the experimental groups post PSBP in favor of the experimental group. This result revealed that the pictorial stories were effective for vocabulary acquisition of KG2 children. 


$$
\text { مجلة كلية التربية بالإسماعيلية - العدد الرابع والأربعون - مايو } 9 \text { م ـ }
$$

Table 6. Two-Tailed t-Test for the Difference in the Mean Scores of the VAR Test of the Experimental Group for Vocabulary Acquisition Pre and Post PSBP

\begin{tabular}{|c|c|c|c|c|}
\hline $\begin{array}{c}\text { Mean of the } \\
\text { differences between } \\
\text { scores of the VAR } \\
\text { Test Pre and Post } \\
\text { PSBP }\end{array}$ & $\begin{array}{c}\text { Standard } \\
\text { Deviation of the } \\
\text { differences }\end{array}$ & $\begin{array}{c}\text { Deviation } \\
\text { Error of the } \\
\text { differences }\end{array}$ & DF & $\begin{array}{c}t- \\
\text { Value }\end{array}$ \\
\hline 32.63 & 5.12 & 1.07 & 22 & 30.49 \\
\hline
\end{tabular}

Since the calculated $t$-value $(30.49)$ is bigger than the two-tailed T-Test value $(t=2.07, p<0.05)$, there is a statistically significant difference in the mean scores of the VAR Test of the experimental group pre and post the PSBP. This result showed that the pictorial stories were effective for vocabulary acquisition of KG2 children. Table 7 Two-Tailed t-Test for the Difference in the Mean Scores of the VAR Test of the Experimental Group for Vocabulary Retention Post and Delayed Post the PSBP

\begin{tabular}{|c|c|c|c|c|}
\hline $\begin{array}{c}\text { Mean of the differences } \\
\text { between scores of the } \\
\text { VAR Test post and } \\
\text { delayed post PSBP }\end{array}$ & $\begin{array}{c}\text { Standard } \\
\text { Deviation } \\
\text { of the } \\
\text { differences }\end{array}$ & $\begin{array}{c}\text { Deviation } \\
\text { Error of the } \\
\text { differences }\end{array}$ & DF & t-Value \\
\hline 0.61 & 4.92 & 1.03 & 22 & 0.59 \\
\hline
\end{tabular}

Since the calculated $t$-value $(0.59)$ is smaller than the two-tailed $T$ - Test value $(t=2.07, p>0.05)$, there is no statistically significant difference in the mean scores of the VAR Test of the experimental group post and delayed post the PSBP. This result revealed that the pictorial stories were effective for vocabulary retention of KG2 children.

A possible explanation for the three results could be summarized as follows:

First, the pictorial stories presented the target vocabulary through interesting contexts and beautiful colorful pictures which helped KG2 children to acquire and retain it. As Sadeghi (2007) assured that the use of pictures facilitates learning and makes words more memorable. Moreover, researchers (e.g. Leny, 2006; Nassar, 2008) stated that pictures are easier to recall and to remember than words, motivate children and direct their attention. Opposed to the technique of teaching vocabulary in isolation from context, many researchers (e.g. Jiang, 2004; Nathanson, 2006; Vernon, 2008) assured that words should be taught in contexts of stories for effectively teaching vocabulary. 
Second, the researcher used both the direct and the indirect methods of teaching the target vocabulary to KG2 children. Applying both methods benefited the children in acquiring and retaining the target vocabulary. This point was assured by researchers (e.g. Apthorp, 2006; Lehr, Osborn and Hiebert, 2009) who stressed that effective instruction must use a variety of methods to help students acquire new vocabulary and it should include opportunities for both incidental word learning and intentional word teaching. Hunt and Beglar (2005) also had the belief that the most effective and efficient vocabulary development would occur in multifaceted curricula that achieve a sound balance between explicit and implicit activities for foreign language learners at all levels of their development.

Pinkley (2009) also stressed the importance of using both types of instruction, namely the direct and indirect. She referred to direct instruction to kindergarten children as a deliberate teaching of a group of target vocabulary items and their meanings. An example might be the pre-teaching of several key items learners will later encounter in a story, through picture cards and posters for kindergarten children which was adapted by the researcher in introducing the target vocabulary. Choudhury (2010) also pointed out that both approaches are important in that proficient intermediate and advanced learners would benefit more from the indirect approach, while beginners would benefit more by a properly structured vocabulary program which can possibly strike a nice balance between explicit teaching and activities providing opportunities for incidental learning.

Third, the researcher read each story more than once and this helped the children more to acquire and retain the target vocabulary. This agreed with studies, such as Senechal and Cornell (1993), Stewart, Heimdal, Hanson, Remhoff and Roy (2011) which stressed that kindergarten children retained new vocabulary from more than a single reading of a storybook.

Fourth, the PSBP included spaced recycled exercises and follow-up activities which helped KG2 children to acquire and retain the target vocabulary, a point which was stressed by researchers (e.g. August, Carlo, Dressler and Snow, 2005; Folse, 2004). Further, the PSBP was suitable for the characteristics of KG2 children in terms of age and cultural background and the number of the pictorial stories and the number of the target vocabulary were convenient to the time of applying the PSBP. 


$$
\text { مجلة كلية التربية بالإسماعيلية - العدد الزرايع والأربعون - مايو } 9 \text { r. }
$$

The results of the present study agree with studies, such as Brooks (2006), Christ (2007), Crawford and Hade (2000), Iannucii, (2007), Senechal (1997) and Walsh and Blewitt (2006) which assured the positive effect of pictorial stories on vocabulary acquisition and retention.

\section{Conclusions}

1. Pictorial stories have a positive effect on the acquisition of the English vocabulary of kindergarten children in EFL classes.

2. Pictorial stories have a positive effect on the retention of the English vocabulary of kindergarten children in EFL classes.

3. Pictorial stories are a suitable teaching method in EFL classes of kindergarten children.

4. Pictorial stories are considered as an attractive and effective way to teach English vocabulary to KG2 children in EFL classes.

\section{Recommendations}

1. Pictorial stories should be part of the English book of KG2 children in experimental English language schools in Egypt.

2. Pictorial stories should be part of the extra-curricular activities of the English language presented to KG2 children in experimental English language schools in Egypt.

3. There should be more interest in varying the activities and making them motivating of the school book of KG2 children of the English language in experimental English language schools.

4. There should be more interest in providing the media rooms with the most modern technological educational aids in Kindergarten of experimental English language schools in Egypt.

5. There should be more interest in providing English courses for facilitators of teaching English to kindergarten children in experimental English language schools in Egypt.

6. There should be more interest in using different kinds of stories for teaching English as a foreign language to KG2 in experimental English language schools in Egypt.

7. There should be criteria for the pictorial stories used in the English curriculum of experimental English language schools in Egypt and their relation to the cultural background of Kindergarten children and their relation to the other topics taught in the other subjects to them to contribute to the integrative curriculum.

8. There should be in-depth studies related to vocabulary retention and its relation to the use of pictorial stories in EFL 
kindergarten classes.

Suggestions for Further Research

1. Comparing the effect of applying different methods of direct instruction of vocabulary and the effect of applying different methods of the indirect instruction of vocabulary in EFL kindergarten classes.

2. The use of pictorial stories with KG2 children to teach them the principles of reading readiness in EFL classes.

3. The use of pictorial stories with KG2 children to teach them the principles of writing readiness in EFL classes.

4. Comparing the effect of presenting pictorial stories with animation and with no animation on vocabulary acquisition and retention of kindergarten children.

5. Comparing the effect of both styles of storytelling and story reading on vocabulary acquisition and vocabulary retention of KG2 in experimental English language schools in Egypt. 
مجلة كلية التربية بالإسماعيلية - العدد الرابع والأربعون - مايو 19 ب P

References

Abbott, M. and Stewart, K. (2007). Cognitive Benefits of Learning

Language. [Available on line]. Retrieved October 11, 2009, from

http://www.actfl.org/i4a/pages/index.cfm?pageid=4724

Abd El-Latif, H. (2007). Effectiveness of Picture Story Book on Reading and Writing Readiness of Kindergarten Children in the Light of Modern Educational Attitudes. M.Ed. Degree, Faculty of Kindergarten, Cairo University (In Arabic).

Abd El-Razek, A. (1995). Phases of the Development of the Ability of Visual Recall of Children ranging between 4-7 years. PH.D. Dissertation, Faculty of Arts, Menya University (In Arabic).

Ahmed, N. (2005). The Effectiveness of a Proposed Program to Study the Effect of Some Kinds of Children's Stories on Developing the Audio and Verbal Skills of Kindergarten Children. M.Ed. Degree, Faculty of Kindergarten Children, Cairo University (In Arabic).

Ahmed, Z. (1994). The effectiveness of using the moving story on the motional and linguistic _development of preschool children. Journal of Faculty of Education in Tanta, 4, 189 (In Arabic).

Almekhlafi, A. (2006). The Effect of Computer Assisted Language Learning (CALL) on United Arab Emirates English as a Foreign Language (EFL) School Students' Achievement and Attitude. Journal of Interactive Learning Research, 17(2), 121-142. [Available on line]. Retrieved March 2, 2011, from http://editlib.org/p/6218

Alexander, F. (1996).Understanding Vocabulary. [Available on line]. Retrieved September 20, 2010, from http://www.Scholastic.com /content/universal/footer.js

Alqahtani, S. (2009). The Role of Using Reading Stories Technique on Teaching English Vocabulary for EFL Learners (Elementary Stage) in Saudi Arabia. MA in Linguistics, the College of Languages and Translation, Imam Muhammad Ibn Saud Islamic University. [Available on line]. Retrieved June 5, 2011, from http://libback.uqu.edu.sa/hipres/ABS/ind8030.pdf.

Apthorp, H. (2006). Effects of a Supplemental Vocabulary Programme in Third Grade Reading/Language Arts. ERIC Document No. EJ773771.

August, D., Carlo, M., Dressler, C. and Snow, C. (2005). The Critical Role of Vocabulary Development for English Language Learners. ERIC Document No. EJ687028 
Biemiller, A. (2003). Vocabulary: Needed if more children are to read well. Reading Psychology, 24, 323-335. [Available on line]. Retrieved June 16, 2010, from http://www.tandfonline.com/doi/ abs/10.1080/02702710390227297

Brabham, G. and Villaume, K. (2002). Vocabulary instruction: Concerns and visions. The Reading Teacher, 56(3). [Available on line]. Retrieved November 14, 2011, from http://www.questia.com /googleScholar.qst?docId $=\mathbf{5 0 0 0 6 7 3 5 7 3}$

Bromley, K. (2007). Nine things every teacher should know about words and vocabulary instruction. Journal of Adolescent and Adult Literacy, 50(7), 528-537. [Available on line]. Retrieved October 6, 2010, from http://www.denison.k12.ia.us/documents /district/NineThingsKnowVocab. Pdf

Brooks, T. (2006). Becoming Acquainted with the Faces of Words: Fostering Vocabulary Development in Kindergarten Students through Storybook Readings. Alabama: Auburn University. [Available on line]. Retrieved June 5, 2011, from http://books.google.com.eg/books/about/Becoming_acquainted_with the faces of wo.html?id=Qjk2twAACAAJ\&redir_esc $=y$

Brown, E. (2004). "Using children's literature with young learners". The Internet TESL Journal, 10(2). [Available on line]. Retrieved January 4, 2009, from http:// iteslj.org/ Techniques/Brown Children's Lit.html

Cherry, K. (2011). What is Validity? [Available on line]. Retrieved June 12, 2011, from http://psychology.about.com/od/research methods/f/validity.htm

Choudhury, A. (2010). Teaching vocabulary in the ESL/EFL classroom: Central pedagogical issues. $M J A L, 2(4), 22-45$. [Available on line]. Retrieved April 12, 2010, from http://www. mjal.org/Journal/Teaching\%20Vocabulary\%20in\%20the\%20ES L EFL\% 20Classroom\%20Central\%20Pedagogical\% 20Issues2. pdf

Christ, T. (2007). Oral Language Exposure and Incidental Vocabulary Acquisition: An Exploration across Kindergarten Classrooms. Ph.D. Dissertation, Faculty of Education, State University of New York. [Available on line]. Retrieved May 11, 2011, from http://proquest.umi.com/pqdlink?did=1338917251\&Fmt=7\&clien tI $d=79356 \& R Q T=309 \& V$ name$=P Q D$ ProQuest document ID: 1338917251

Collins, F. (2010). ELL preschoolers English vocabulary acquisition from storybook reading. Early Childhood Research Quarterly, 25(1), 84-97. [Available on line]. Retrieved July 3, 2011, from 


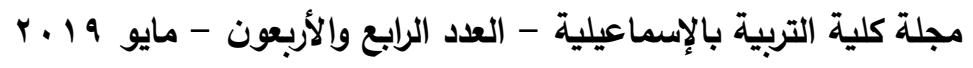

http://www.mendely.com/research/ell-preschoolers-english-

vocabulary-acquisition-from-storybook-reading

Coyone, M., McCoach, B. and Kapp, S. (2007). Vocabulary

intervention for kindergarten students: Comparing extended

instruction to embedded instruction and incidental exposure.

Learning Disability Quarterly, 30(2), 74. [Available on line].

Retrieved November 4, 2011, from http:// www.jstor.org/pss/ 30035543

Crawford, P. and Hade, D. (2000). Inside the Picture, Outside the Frame: Semiotics and the Reading of Wordless Picture Books. ERIC Document No. EJ623711

Day, R., Omura, C. and Hiramatsu, M. (1991). Incidental EFL vocabulary learning and reading. Reading in a Foreign Language, 7(2), 541-551.[Available on line]. Retrieved February 15, 2010, from http://pweb.sophia.ac.jp/linstic/applied/youyaku/yoshi02.html

Diab, M. (1999). An Introduction to the Culture and Literature of Children. Cairo: International Dar of Publishing and Distribution (In Arabic).

El-Bosat, A. (2005). Children Read Between the Desire of Parents and the Word of Children. Cairo: Modern Dar EI Kotob (In Arabic).

El-Gadry, L. (2003). The Story in Children's Literature. [Available on line]. Retrieved February 28, 2011, from www.mandaee.com/ index.php?option $=$ com content\&view $=$ article\&id $=267$ (In Arabic).

El-Hadidy, A. (1996). In Children's Literature. Cairo: Anglo Bookshop (In Arabic).

El-Monayyer, R. (2002). Effectiveness of an Activity Program on the Development of the Creative Thinking of Pre School Children. M.ED. Degree, Isamilia Faculty of Education, Suez Canal University (In Arabic).

El-Tartoory, M. (2009). The Linguistic Development of Kindergarten Children. [Available on line]. Retrieved March 11, 2009, from http://www.horoof.com/dirasat/childlang.html (In Arabic).

Folse, K. (2004). The underestimated importance of vocabulary in the foreign language classroom. Clear News, 8(2), 1-6. [Available on line]. Retrieved January 2, 2010, from http://www.seasite.niu.edu/trans/articles/Underestimated\%20Importa nce $\% 20$ of $\% 20$ Vocab.htm

Gass, S. and Selinker, L. (1994). Second Language Acquisition: An introductory Course. Amsterdam: John Benjamins.

Grace, C. (1998). Retention of word meanings inferred from context and sentence-level translations: Implications for the design of beginning-level CALL software. ERIC Document No. EJ575506 
Greenwood, C. and Flanigan, K. (2007). Overlapping vocabulary and comprehension: Context clues compliment semantic gradients. Reading Teacher, 61(3), 249-254. [Available on line]. Retrieved July 6, 2011, from http://online librarywiley.com/doi/10.1598/RT.61.3.5/abstract

Halliday, K. (1988). Language as Social Semiotic, London: Edward Arnold.

Herendeen, N. (1995). The Art of Storytelling: Guide for Teachers. Brooklyn: NY.

Herman, A. and Dole, J. (1988). Theory and Practice in Vocabulary Learning and Instruction. ERIC Document No. EJ377919

Hunt, A. and Beglar, D. (2005). A framework for developing EFL reading vocabulary. Reading in a Foreign Language, 17(1). [Available on line]. Retrieved August 2, 2009, from http://nflrc.hawaii.edu/rfl/april2005/hunt/hunt.html

Hussein, K. (1999). Entry to Children's Literature. Cairo: El-Omrania Press (In Arabic).

Iannucci, C. (2007). Repeated Interactive Read-Alouds in Preschool and Kindergarten. [Available on line]. Retrieved March 10, 2010, from http://ici-bostonready-pd-2009-2010.wikispaces.umb.edu /file/ view/Repeated + Interactive+ Read-Alouds + in Preschool \%26K+-+Reading+Rockets+Iannucci.pdf

Ibrahim, A. (1987). The Development of Scientific Concepts and Special Methods of Kindergarten Children. Cairo: Anglo Bookshop (In Arabic).

Isbell, R., Sobol, J., Lindauer, L. and Lowrance, A. (2004). The Effects of Storytelling and Story Reading on the Oral Language Complexity and Story Comprehension of Young Children. ERIC Document No. EJ732281

Jiang, N. (2004). Semantic Transfer and its Implications for Vocabulary Teaching in a Second Language. ERIC Document No. EJ687059

Justice, M. and Pullen, C. (2003). Promising interventions for promoting emergent literacy skills: Three evidence-based approaches. ERIC Document No. EJ678699

Khedr, A. (2007). The Effect of Learning a Foreign Language in an Early Age on the Linguistic Development of the Child. Cairo: Modern Dar El Kotob (In Arabic).

Kies, D. (2009). Modern English Grammar: Language Development in Children. [Available on line]. Retrieved May14, 2010, from http:// papyr.com/hypertext books/grammar/Igdev.htm 
مجلة كلية التربية بالإسماعيلية - العدد الرابع والأربعون - مايو 9 بـ

Laufer, B. (2001). Reading, word-focused activities and incidental vocabulary acquisition in a second language. ERIC Document No. EJ637433

Lehr, F., Osborn, J. and Hiebert, E. (2009). A Focus on Vocabulary. [Available on line]. Retrieved September 13, 2011, from http:// www.prel.org/products/ re_/ Es0419.htm

Leny, N. (2006). Teaching Vocabulary through Pictures to the Kindergarten Students. A thesis for the requirements of the degree of Sarjana in Education, Faculty of Tarbiyah and Teachers Training, Syarif Hidayatullah State Islamic University. [Available on line]. Retrieved February 26, 2011, from http:// idb4.wikispaces.com/file/view/THEACHING+VOCABULARY+ THROUGH+PICTURES/+TO+THE+KINDERGARTEN+ STUDENTS0.pdf

Martinez, B. (2007). A story-based approach to teaching English. Encuentro, 17, 52-56. [Available on line]. Retrieved April 1, 2010, from http://www.encuentrojournal.org/textos/lllan.pdf

McGee, L. and Schickedanz, J. (2007). Repeated Interactive ReadAlouds in Preschool and Kindergarten. [Available on line]. Retrieved May 4, 2011, from http://www.readingrockets.org/ themes/rr new/style/main 2010 .css

Miedel, T. and Reynolds, J. (1999). Parent involvement in early intervention for disadvantaged children: does it matter? Journal of School Psychology, 37(4), 379-402. [Available on line]. Retrieved November 2, 2011, from http://www.sciencedirect. Com /science/article/pii/Soo22440599000230

Mohamed, D. (2004). The Effectiveness of a Program Based on Cooperative Learning for Visually Impaired Students at the Primary Stage on Developing their English Vocabulary. M.Ed. Degree, Faculty of Education, Ain Shams University.

Mukdady, M. (2007). The Story in Children's Literature in Jordan. [Available on line]. Retrieved January 18, 2009, from http:// abdulkareemmokelan.maktoobblog.com/19/boystorystyle (In Arabic).

Mustafa, F. (2002). Preparing the Child to Read in Kindergarten. Cairo: Arabic Dar Library for Books (In Arabic).

Najjar, L. (1998). Principles of educational multimedia user interface design. Human Factors, 40(2), 311-323.[Available on line]. Retrieved March 12, 2011, from http://www. Informatikdidaktik .de/HyFISCH/Multimedia/Learning/MMDesignNajjar.htm

Nassar, H. (2008). Color and Pictures in Children's Learning. Cairo: Anglo Bookshop (In Arabic). 
Nathanson, S. (2006). Harnessing the power of story: Using narrative reading and writing across content areas. Reading Horizons, 47 (1), 1-26. [Available on line]. Retrieved May 4, 2011, from http://scholarworks.wmich.edu/reading horizons/vol47/iss1/2/

Nation, P. (2001). Learning Vocabulary in Another Language. Cambridge: Cambridge University Press.

National Reading Panel. (2000). Comprehension Part 1: Vocabulary Instruction. [Available on line]. Retrieved March 3, 2012, from http://www.nichd.nih.gov/publications/nrp/upload/ch4-I.pdf

Pinkley, D. (2009). Children Learning English as a Foreign Language: Teaching Vocabulary Effectively. NY: Pearson Longman.

Putri, H. (2010). The Importance of Vocabulary in English Learning. [Available on line]. Retrieved July 3, 2011, from http://university ofibnkhaldunbogorindonesia.blogspot.com/2010/ 01/importanceof-vocabulary-in-english.html

Sadeghi, M. (2007). The Use of Posters and Vocabulary

Improvement in Rural Areas. [Available on line]. Retrieved June 19, 2010, from http:// www.articlebase.com/educate-articles/the-useof-posters-and-vocabulary-improvement-in-rural-areas-90714.html

Saeed, E. (2007). Effectiveness of Using Children's Stories as a Source of Artistic Expression on Developing the Creative Thinking of Pre School Children. M.Ed. Degree, Faculty of Education, Om El-Kora University. [Available on line]. Retrieved February 25, 2011, from http:// English.tyhs.edu.tw/ epaper/ epaper 35/teach_35.pdf (In Arabic).

Senechal, M. and Cornell, E. (1993). Vocabulary Acquisition through Shared Reading Experiences. ERIC Document No. EJ472400

Senechal, M. (1997). The Differential Effect of Storybook Reading on Preschoolers' Acquisition of Expressive and Receptive Vocabulary. ERIC Document No. EJ547516

Sherif, N. (1990). Psychological Bases of Educational Experiences and their Application for the Learning and Teaching of the Child. Kuwait: El-Kalam Dar of Publishing and Distribution (In Arabic).

Sokmen, A. (1997). Current Trends in Teaching Second Language Vocabulary. Cambridge: Cambridge University Press

Stewart, L., Heimdal, S., Hanson, T., Remhoff, J. and Roy, L. (2011). Increasing Vocabulary Knowledge in Preschoolers through Repeated Read-Alouds. [Available on line]. Retrieved March 12, 2011,fromhttp://www.nasponline.org/conventions/2011/handouts /SY/NASPVocabStudyRRASP2011 Stewart.ppt 


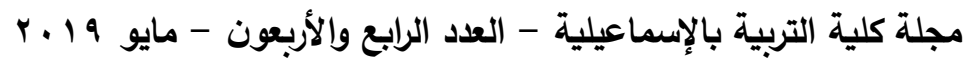

Suzuki, K., \& Takahashi, R. (2002). Effectiveness of color in picture recognition memory. Japanese Psychological Research, 39(1),2532. [Available on line]. Retrieved November 4, 2010, from http://onlinelibrary.wiley.com/doi/10.1111/1468-5884.00033/abstract

Thornbury, S. (2004). How to Teach Vocabulary. Essex: Pearson Education Limited.

Vernon, S. (2008). Teaching English Games. [Available on line]. Retrieved December 8, 2010, from http://Teaching english games.com/3-5.htm

Vygotsky, L. (1989). Thought and Language, Cambridge, Mass.: M.I.T. Press

Walsh, B. and Blewitt, P. (2006). The Effect of Questioning Style During Storybook Reading on Novel Vocabulary Acquisition of Preschoolers. ERIC Document No. EJ747238

Wilkins, D. A. (1972). Linguistics in Language Teaching. London: Arnold.

Wright, A. (2000). Stories and their importance in language teaching. Humanizing Language Teaching, 2(5). [Available on line]. Retrieved May 5, 2010, from http://www.hltmag.co.uk/sep00/ mart2.htm

Wu, S. (2008). Teaching the three little pigs to EFL young learners in Taiwan. The Internet TESL Journal, 14(1). [Available on line]. Retrieved February 2, 2011, from http://iteslj.org/ Techniques/WuTeachingFolktales.html 
استخدام القصص المصورة لإكساب أطفال الروضة مفردات اللغة الإنجليزيـــة و

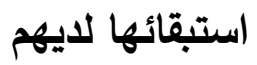

تناولت الدراسة الحالية أثر القصص المصورة على اكتساب مفردات اللغة الإنجليزية

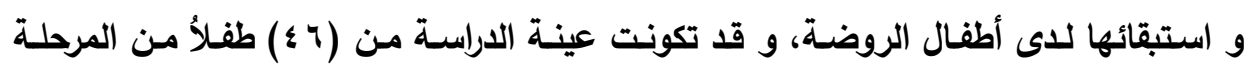

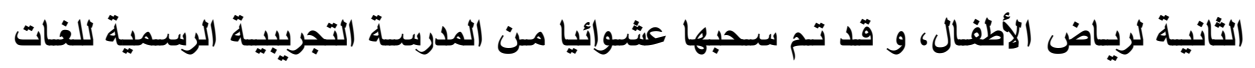

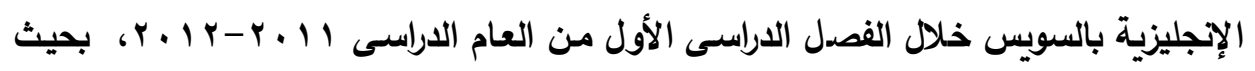

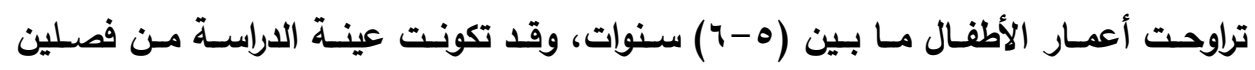

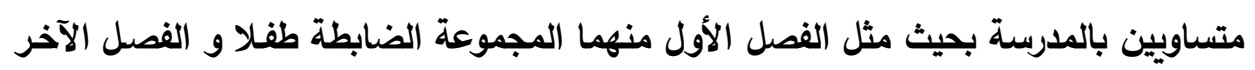

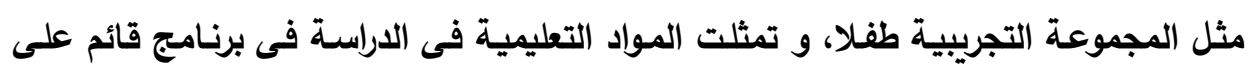

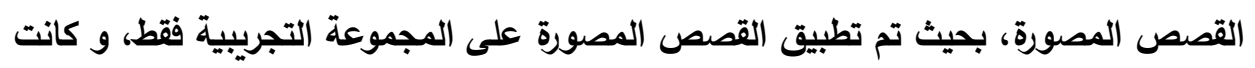

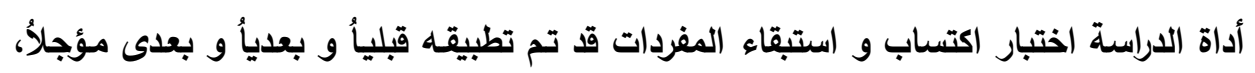

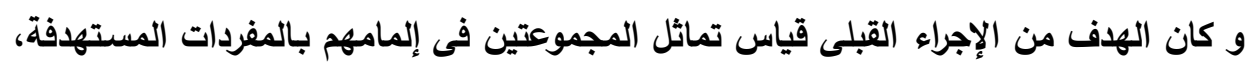

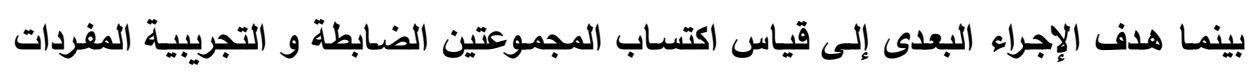

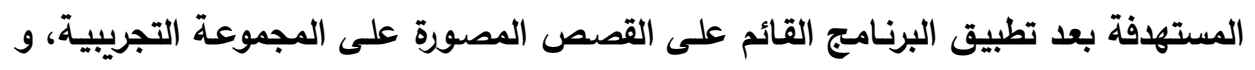

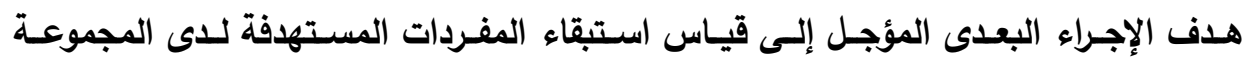

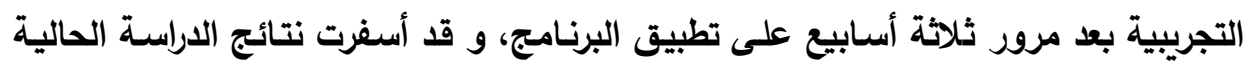

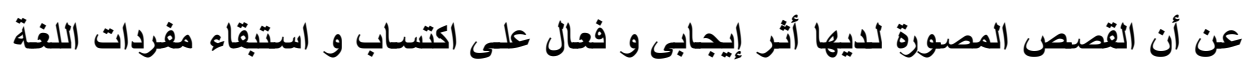
الإنجليزية كلغة أجنبية فى رياض الأطفال. 
مجلة كلية التربية بالإسماعيلية - العدد الرابع والأربعون - مايو 9 ب. P

Abstract

This study aimed to explore the effect of pictorial stories on the acquisition and retention of English vocabulary in kindergarten. The participants of the study were 46 kindergarten children of the second phase (KG2) whose ages ranged from (5-6) years old. They were randomly drawn from Suez Experimental English Language School during the first term of the school year 2011-2012. They were divided into two groups: the control group ( 23 children) and the experimental group ( 23 children). The instructional materials of the study were represented in a Pictorial Stories Based-Program (PSBP). The control group was not exposed to the pictorial stories, while the experimental one was exposed to the pictorial stories. The instrument of the study was the Vocabulary Acquisition and Retention (VAR) Test that was pre, post and delayed post administered the PSBP. The pre-administration was intended to measure the equivalence of both the control and experimental groups of KG2 children in their knowledge of the target vocabulary. The post-administration was intended to measure the acquisition of the target vocabulary of both the control and experimental groups after administering the PSBP to the experimental group. The delayed post-administration measured the retention of the target vocabulary of the experimental group after three weeks of applying the PSBP. Differences in the mean scores between the tests were analyzed by using the two-tailed t-test. The results revealed that the pictorial stories were effective for vocabulary acquisition and retention of KG2 children. 